\title{
THE OTAGO PENINSULA, A UNIQUE IDENTITY
}

[Received December 15th 2015; accepted March 5th 2016 - DOI: 10.21463/shima.10.1.o8]

\section{MEGAN POTIKI}

Otago University, Dunedin <megan.potiki@otago.ac.nz >

\begin{abstract}
The Otago Peninsula on the South Island of New Zealand has a long indigenous Mãori history that is rooted in the land and the people of the area. The stories and genealogy that connect Māori New Zealanders to the Otago Peninsula are well documented and retold. After European contact with and connection to the Otago Peninsula was initiated the colonisation of the area occurred rapidly. The Otago Peninsula historically, and to the modern day, has always had a separate character to that of the adjacent mainland (around the city of Dunedin). Despite the short distance between them, the culture of the Otago Peninsula remains distinct to that of the mainland as if it were an island.
\end{abstract}

KEYWORDS: Otago Peninsula, Māori, Ōtākou, history, indigenous, insider

\section{Introduction}

Historically the Otago Peninsula was exceptionally important to the indigenous people of the area, the Māori of southern New Zealand. Their relationship with the Peninsula was one based on creation mythology, spiritual beliefs and gods, warfare, intermarriage and livelihood. The arrival of Europeans and the interrelationships that occurred have created a culture on the Otago Peninsula that is different to that of the mainland. The Peninsula community is underpinned by one thousand years of Māori occupation and a new identity has emerged that is distinct from the mainland.

I am writing from an insider's perspective. Rewi defines the insider in research:

as a person who is in a position of privilege by way of kinship relation-ship, immediate or extended. In this vein, being classified as an insider infers access to deeper levels of knowledge. (2014: 246)

I am a descendant of the original indigenous inhabitants of the Otago Peninsula. I was raised on a farm near the harbour entrance of the Peninsula, therefore, my connection is deeply rooted to the land through whakapapa (genealogy). As Baldacchino states, this is not a perspective that should be read as exclusive (2008: 50). However it is a voice that can contribute value and vibrancy to the academic pursuit of Nissology. Baldacchino's commentary as an islander stresses a greater attention to the 'insider perspective' and that of the indigenous experience:

And while islands' contribution to endemic life and culture is recognized and celebrated, it is often outsiders - rather than insiders - who discover, 


\section{Potiki: Otago Peninsula}

investigate and proclaim such endemism and diversity to the rest of the world. The problematique of island enquiry is that there will always be epistemological and methodological challenges associated with studying islands, because we are grappling with the impact, conditioning and paradigmatic effects of the hybrid identity and 'location' of subjects (islanders, natives, settlers, tourists, second home owners), as well as those who would study them - who may be locals as well as outsiders (mainlanders, continental dwellers) - looking in. (2008: 38)

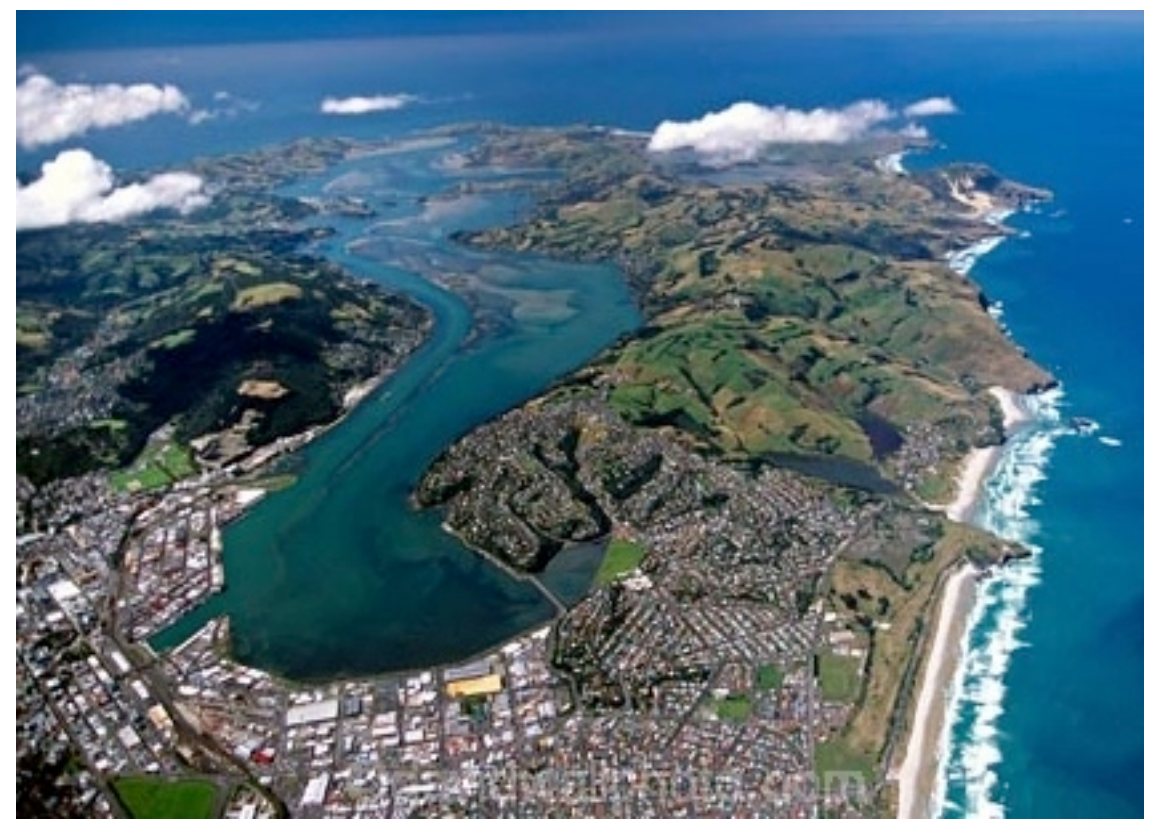

Figure 1 - Aerial view of the Otago Peninsula (centre right of image) (Courtesy of David Wall Photography (http://www.davidwallphoto.com/detail/6169-Dunedin,-OtagoHarbour-and-Otago-Peninsula-_-aerial.html)

The Otago Peninsula is situated on the east coast of the South Island of New Zealand. It extends eastward, out from the city of Dunedin. Today, Dunedin is the second largest city in the South Island and is built on a number of valleys and hills that overlook the remains of extinct volcano rock named the Otago Peninsula. This was a shield volcano that began erupting around 16 million years ago and had three main eruptive phases. The Dunedin city area, Portobello and the Otago Harbour are all part of the volcano. Its peak was possibly as high as 10oom but it has been eroded over millions of years. The area between Port Chalmers and Portobello was the vent of the volcano and is now part of Otago Harbour. The sea has drowned the lower slopes of the volcano and outcrops of lava and ash are visible around the city and the harbour (GNS Science, 2015: online).

In the hearts and minds of many local people, the Otago Peninsula is merely connected to the mainland by a narrow isthmus, about 1.5 kilometers wide. However the main highway from the Peninsula to the city is via a man made causeway across Anderson's Bay inlet, on the south west side of the Peninsula. This fosters the identity of Peninsula dwellers as 


\section{Potiki: Otago Peninsula}

separate to that of the mainland as if living on 'almost an island' and this type of human engineering has not de-islanded the community in any manner. There have been local art exhibitions, a book published and a prestigious Conservation Conference named 'Almost an Island', dedicated to the Otago Peninsula as its own entity. Sorrell and Warman have also asserted that:

Otago Peninsula has not quite escaped the grip of the mainland. It has often been characterized as 'almost an island' and when sea levels rose around 6500 years ago it was an island, only to reforge a connection with its parent landform. (2013: 7)

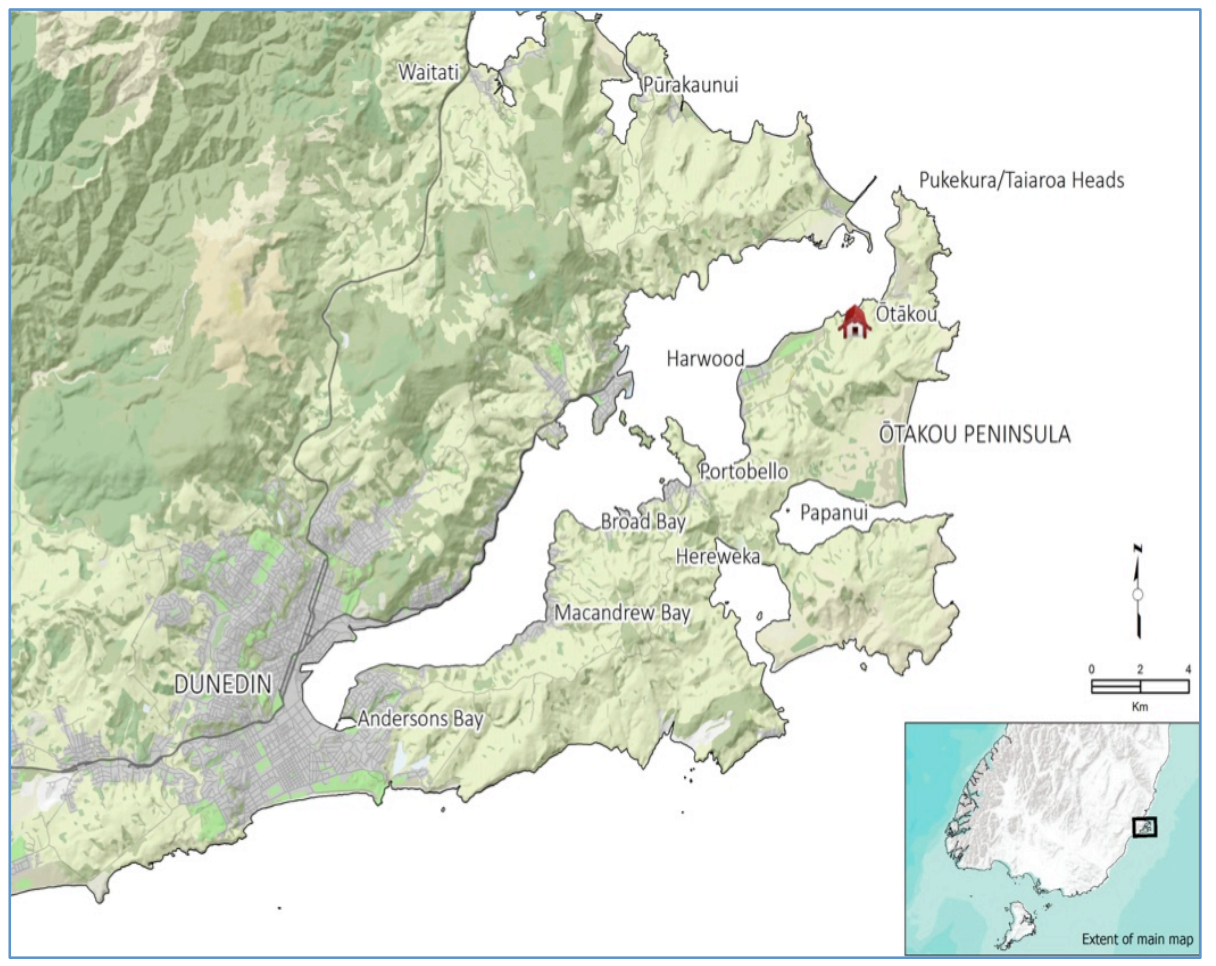

Figure 2 - Map of the Otago Peninsula (Gover, I 2015, Te Rūnanga o Ngāi Tahu) Designed for the purpose of this article.

\footnotetext{
${ }^{1}$ Otago Peninsula Artists 'Almost an Island' Art Exhibition (2015) - see: http://www.otagopeninsula.co.nz/OpenArts/Newsletters/2015jan.pdf - accessed February 15th 2016. 'Almost an IslandValuing the Otago Peninsula' a conference held in 2013 in Dunedin, see: http://www.yelloweyedpenguin.org.nz/people/news-and-updates/almost-an-island conference-programme - accessed February 15th 2016. Also see Morris and Forsyth (1986).
} 


\title{
Potiki: Otago Peninsula
}

\section{Māori and the Otago Peninsula}

The Peninsula has a long history of occupation beginning with that of Māori, the indigenous people of New Zealand. The origin of how the Peninsula was formed has been cemented in Southern Māori narratives. The original people of the area were known as Kāti Hāwea and Te Rapuwai. Anderson maintains that these people were Polynesians and among the ancestors of Southern Māori (1983: 4). Their imprint can be traced through placenames in the area. The next group of people were the Waitaha ${ }^{2}$ and their story is also embedded in placenames. They are an early iwi (tribe) who are known to have arrived on the Üruao canoe. Rākaihautū, of the Waitaha people, who is well known in Southern Māori traditions, was described as a giant. He carved out the lakes and rivers of the South Island with his supernatural digging implement (New Zealand Geographical Board, 1990: 90-91). Creation stories are pivotal in cultures, whakapono (beliefs and religion) and environments. Over time, humanity has constructed a way to explain how nature, humanity and particular convictions and behavior occurred. Equally, Mãori in the most southern reaches of Polynesia have validated themselves with their own stories and whakapapa (genealogy):

The world was a mirror of their lives. Light and darkness were personified as male and female elements. Heaven and earth were projections of one's father and mother. With these primal elements established, the world of plants, fish, rocks and stars was ordered and understood as a cosmic family. (Tau, 2001: 138)

The southern Māori account of creation is similar to many Eastern Polynesian stories that incorporates the activities of the gods such as Raki (the Sky Father) and Papatūānuku (the Earth Mother) and their many offspring who produced and fashioned the natural world of the environment, celestial realms and mankind.

Southern Māori are now void of all traditional native speakers, however we are fortunate that very early missionary interaction meant that oral records were kept relatively intact. There are a number of southern Māori informants from the 19th Century who not only provided information for missionaries to record but who were also scribes of their own stories and whakapapa. One well-known tohunga (specialist) was Matiaha Tiramorehu. A detailed account of Tiramorehu's knowledge of creation was recorded by Reverend Charles Creed during the 1840 . It explains the geneses of the mountains, the winds, the universe, life, death, planetary domains, flora and fauna, and fundamental human values. The first specific reference to the Otago Peninsula was in regards to the Te Waka o Aoraki tradition.

\footnotetext{
${ }^{2}$ Representations of Waitaha as a type of peace loving, First Nations' people with an ability to talk to trees and stones have been controversial and have created some tensions within our tribe today. In recent years there has also been a rise in those claiming solely Waitaha genealogy. This claim has not generally been supported by the majority, particularly our tribal leaders and many kaumātua. O'Regan states that "much of the surviving knowledge which can be traced back to Waitaha within our traditions is esoteric and, therefore, subject to a considerable amount of interpretation and, indeed, a variety of opinion" (2003: 22) Prendergast-Tarena attributes the emergence of a Waitaha tradition to a political and spiritual movement created by a Southern 'guru' in the late 1870s, named Te Maihāroa. "Although elements of Waitaha traditions were existent pre-contact, there was not a cohesive body of traditions until the 188 os which is late in comparison to the earliest recorded South Island traditions and follows the establishment of Te Maihāroa's wharekura" (2008: 354).
}

\author{
Shima: The International Journal of Research into Island Cultures \\ Volume 10 Number 12016




\section{Potiki: Otago Peninsula}

Aoraki was one of the senior progeny from Raki's first marriage to Pokohāruatepō. Raki's second marriage was to Papatūānuku. Aoraki and his brothers were interested in Raki's new wife and descended from the heavens in their waka (canoe) to greet Papatūannuku. The meeting appears to have been good-natured but when Aoraki attempted to once again ascend to their celestial home a mistake was made in the karakia (prayer) and the canoe met with trouble. Aoraki and his crew clambered to high ground but were caught by the rays of the sun and were turned to stone, becoming the highest peaks of the Southern Alps. It was the nephew of Aoraki, Tüterakiwhanoa, who was asked to find the whereabouts of his uncles and he discovered that they and their waka had become an island in the ocean. After a period of lament he took his great adze, Te Hamo, and set about shaping the canoe and its inhabitants so that it could be a livable land mass. He carved out the sounds in Fiordland and Marlborough and also formed the peninsulas along the eastern seaboard including the Otago, Huriawa and the Moeraki peninsulas. He left guardians in place, namely Kahukura and Rokonuiatau. Beattie refers to the Otago Peninsula in this narrative of creation as Mua-upoko (Beattie, 1949: 8) According to our ancestors, these atua kaitiaki (guardians) remained in on the Otago Peninsula right up until the time the old religion and beliefs were abandoned and Christianity was adopted. H.K. Taiaroa was a well-known leader, scholar and New Zealand Māori politician of his time. ${ }^{3} \mathrm{He}$ was born in the 1830 or 1840 os and hailed from the Peninsula. Taiaroa. maintained in one of his diary extracts from 1865 that he saw the demi god Kahukura at a place (unnamed) on the Otago Peninsula. He described a cliff edge that was covered in sand and beside this area was a sacred tuahu (altar) where Kahukura abided. Taiaroa stated that "with his own eyes he could see the spirits of the tohunga (specialist healers) of that site who had gathered there to guard and protect the area" (Taiaroa, $1865^{4}$ ).

Cowan retells a story of the physical tuahu that was stolen from a fortified village near the Otago Peninsula. This was a result of a battle between closely related sub-tribes of the Peninsula and the neighboring northern village. A carved image of Kahukura was kept with the sacred altar. "The spot was called Te Irika o Kahu-kura, meaning the place where Kahukura was suspended or raised up to view" (Cowan, 1987: 4). The Otago Peninsula, along with other peninsulas along the East Coast of the South Island, were protected by these demi-gods. These were gods who were not the highest celestial beings but those closer to man who manifested themselves in nature and as guardians of people. Through them Māori connected geographically and spiritually to the Peninsula.

The early occupation of the Peninsula was immediately focused at the entrance of the harbour rather than near the mainland or across the Peninsula. This focal area is still occupied today by the descendants of the first people to reach the area. The name Muaupoko, has recently been adopted by our own people as the over-arching Māori designation for the Otago Peninsula. However this has occurred as a result of a Western desire to name and re-name places that suits its paradigms of understanding and interpreting geography. Stevens discusses this tension about the Māori name of the Southland area of the South Island, Murihiku.

\footnotetext{
${ }^{3}$ H.K. Taiaroa has been written about in articles, books and commented on in many other sources. (See Pōtiki, 2015.)

${ }^{4}$ Translated from H.K. Taiaroa's diary by Megan Pōtiki (2014) for the purpose of a presentation at the University of Otago entitled' Killing Demons and Cultural Collisions', see: http://blog.otago.ac.nz/tetumuresearch/tag/taipo/ - accessed March 20th 2016.
} 


\section{Potiki: Otago Peninsula}

Present usage may in fact say more about colonial encounter, and its power to modify indigenous placenames and meanings, and produce new and abiding categories of thought. This suggests that we should pay more attention to the interplay of space, place and colonialism, and complicate our view of them. (2001: 334)

Re-naming and labeling places with placenames is inherent in the evolution of culture and it is important to accept that it is the nature of rebuilding culture.

Integral to processes of place creation, belonging and attachment, toponyms are sites of relative stability that memoralise persons, events and social relations by imprinting the landscape with the accretion of human action. (Nash and Low, 2015: 405)

However with merely one source to the name Muaupoko, from Herries Beattie in 1915, it has a spurious attachment to the Otago Peninsula. Furthermore, Muaupoko is not mentioned in the original Deed of Sale of Otago. The Otago Deed was signed by twenty three Māori leaders and two 'proxies' on the $31^{\text {st }}$ July 1844 at Kōpūtai across the harbour from the Otago Peninsula (Evison, 2006: 51). The name and the spatial idea of Muaupoko does not represent how our people occupied the land. This supports the argument for the distinctive nature of the Peninsula shaped by the long-standing Māori occupation of certain areas and their behavior as if living on 'almost an island'. This raises the question of where the specific areas of occupation and importance on the Otago Peninsula were. Ōtākou is a significant name for the area and Beattie explains how it eventually became a more probable name for the Peninsula:

The word came from Hawaiiki and was applied to a current in the harbor. It was the whalers who altered the site of the name from sea to land by extending the word Otago from the harbour to the Peninsula. (1944: 47)

Originally Ōtākou was the name of the waterway that spans the area from Taiaroa Heads to Harwood township (Taylor, 1950: 130). Although it is an ocean harbor, it was known as an awa (river) by our old people because of its river-like appearance. (Church, 2008: 102103). It has been stated that "I am Ōtākou river, Ōtākou river is me" (Ellison, 2011: 1). There is an old story that talks of a taniwha (monster) named Matamata scooping out the Otago Harbour and defining its river-like shape (Pybus, 1954a: 33). There are some islands dotted in the centre of the Otago Harbour but there is no evidence of Māori occupation on these. The islands have Māori names and also more recent European ones. The toponymic ethnography of the Otago Peninsula, including these small islands, illustrates the deep spiritual connection Māori had with features of the land. Nash defines "toponymic ethnography":

as a method that considers both the linguistic structure and cultural significance of topynyms as a key to writing, describing and understanding linguistic, cultural and ecological relationships between people and place. (2012: 80) 


\section{Potiki: Otago Peninsula}

Furthermore, Māori have navigated their path across the vast ocean naming places across the large archipelago of the Pacific ${ }^{5}$. They brought names to New Zealand that were familiar and placed them on the landscape. The smallest island in the Otago Harbour is known as Titere Moana, a name that is observed in many places throughout New Zealand and in the wider Pacific. The larger of the Islands is known as Kamautaurua, a name that is repeated in other places in the South Island. Kamautaurua became Quarantine Island as settlers were taken with various illnesses when they arrived to Dunedin. The island between these two is known as Rakiriri and was known as the abode of Takaroa (the guardian of the sea). There is also a tiny island in Papanui Inlet that is of great significance to local Māori. The story of Kāpō is central to the naming of the island and this is addressed in detail below. The transferal of this place-name and its story to each generation has elevated the tiny island to a sacred and important status. The lengthy name of the island (Te-taka-ki-taka-o-te-piro-o-Kāpō) refers to the place where Kāpō was disemboweled, cooked and eaten by Te Wera's men in battle (Taylor, 1950: 132). The esoteric toponyms that are referred to by Nash (2014: 177) illustrate the profound attachment Māori have to the Otago Peninsula landscape. Kelly refers to a well-known European ethnologist from the South Island, Herries, who:

\section{talked with elders, who passed on to him their knowledge of how their ancestors came to these islands, and while the accounts vary in detail and some spellings, they clearly describe either the same sequence of events or a learned story from a similar source. (1999: 12)}

Today however, Ōtākou is more widely recognised in the Otago area as the name for the entire harbour and the settlement at the lower end of the Otago Peninsula (Reed and Reed, 1951: 122). Otago eventually became the name for that entire southern region, being a modified version of Ōtākou. ${ }^{6}$ There is historical evidence that Ôtākou as a place name is an ancient name stemming from Hawaiiki (West, 2009: 79 and Beattie, 1944a: 46) The origins of the meaning are obscure although as Beattie has recorded, the word kou in Ōtākou means a jutting point or an end point (ibid). This is quite possibly a description of the shape of the area of Ōtākou.

Ōtākou is located on on the eastern side of the Otago harbour. Although it is situated approximately 25 kilometres from Dunedin city it is within the boundaries of the wider Dunedin area. Today you would take an approximate thirty minute drive from the mainland to reach Ōtākou with a further five minutes on to the tip of the Peninsula known as Taiaroa Heads. Taiaroa Heads is famously known as the location of then world's only

\footnotetext{
${ }^{5}$ Hau'ofa's (1998) work on regional identity for Pacific Islanders comments these connections across Oceania. Stratford et al (2011) write about the Islands of the Pacific as an archipelago.

${ }^{6}$ There has been on-going debate about the origins of the name Otago for this entire southern region. Entwisle (1998: 136-139) argues that that early written records of the name of the area as Otago reflect the guttural dialect of the local Māori and the "k" of Ōtākou was pronounced as a "g" like the word "cargo" or "Otargo". Begg \& Begg (Begg, 1979: 271) state that Boultbee records the name of the area also as "Otargo" reflecting the dialect and pronunciation of the Māori language in that area. Evison (Evison, 1993: 219) also includes a written record of the name "Otago" by Monroe in 1844 stating that this clearly reflected the Maori pronunciation of this name in this area. Beattie (1944: 46) and G.B. Stevenson (1947: 134) both claim that "Otago" is a clone of the original place name of "Ōtākou".
}

\section{Shima: The International Journal of Research into Island Cultures Volume 10 Number 12016}




\section{Potiki: Otago Peninsula}

mainland colony of Royal Albatross. Ōtākou is referred to as the kaik (village) ${ }^{7}$ situated below Portobello. Mainland residents knew this area as the kaik and this remains today.

The tangata whenua (indigenous people) of contemporary Ōtākou originate from a number of different tribal groups. It would be simply impossible for someone who has whakapapa to Ōtākou to claim to merely one iwi or hapū. Durie describes hapū as:

fluid, constantly changing, dividing as numbers increased, or fusing if due to war or famine numbers were reduced. In the result there were generally many hapu in any natural geographic region, which, through historic genealogies reinforced by continuing inter-marriage, were all related. (1996: 449).

The Hawea, Te Rapuwai and Waitaha people were the first groups of early Southern Polynesians to occupy this area, as has been previously mentioned. The earliest activity on the Otago Peninsula was in AD 1150-130o, according to Anderson (1983: 7), describing moa butchery sites, including one at Harwood on the Peninsula and one at Andersons Bay on the mainland. ${ }^{8}$

The following wave of people migrated in different phases from the North Island and married into these existing groups of people. The Kāti Mamoe ${ }^{9}$ migration was the first in the series of migrations south. According to many accounts Kāti Mamoe are descendants of a woman called Hotu Mamoe who hailed from the North Island area of Napier (Beattie, 1920: 189). There is evidence that the arrival of Kāti Māmoe occurred after Waitaha's settlement and before the final migration of Kāi Tahu. Anderson writes that "by about the late sixteenth century, some groups of Ngāti Mamoe had begun to settle in the South Island" (1998: 23). Evidence of their early occupation has been recalled in stories and whakapapa about the local landscape, including the Otago Peninsula. As previously mentioned, Pybus refers to a local kaitiaki (guardian) named Matamata that was a lizard. According to Pybus, Hoani Karetai, the paramount chief of Ōtākou, used to speak about a taniwha that was the guardian of the spirit of a famous Kāti Mamoe chief. This taniwha lost its master and set out in search of him. It wriggled, causing sharp bends and twists in the river and eventually scooped out the Otago Harbour. The monster now lies solidified as a hill on the mainland (Pybus, 1954a: 33). The migrants that followed Kāti Māmoe were descendants of an individual from the East Coast of the North Island known as Tahupōtiki. The Kāi Tahu tribe is a well-known Māori entity in South Island today and takes its name from the eponymous ancestor, Tahupōtiki. Tahupōtiki lived his life in the North Island on the East Coast around the area now known as Hawkes Bay. According to Anderson there was considerable continuity in the southern Māori population. Anderson describes the migration as piecemeal, and at a clan and family level, during which each group set about consolidating its position by pursuing, in about equal measure, feuding and intermarriage (1983: 46).

\footnotetext{
${ }^{7}$ A Southern word for village that stems from the word Kāika (village) or Käinga in the North Island dialect of the Māori language.

${ }^{8}$ The moa is a type of flightless, extinct bird of New Zealand similar to the emu. The largest of all moa (Dinornis giganteus) could reach a height of four meters and was relatively simple to hunt. Moa were extinct before the arrival of Europeans in New Zealand (Anderson, 1983: 9).

${ }^{9}$ Kāti Mamoe is also known in a Northern dialect as Ngāti Mamoe.
} 


\section{Potiki: Otago Peninsula}

The detail about Mãori migration south has remained relatively intact because of the insular biogeography of this most southern indigenous habitat. A clear picture of the migration south has been allowed through the passing on of oral traditions and a strong body of written records from missionaries and some key indigenous informants. These comprehensive historical narratives about Kāi Tahu's migration include the Kāti Māmoe history. There is a common perception of a sparring relationship between Kāti Māmoe and Kāi Tahu culminating in a power struggle over land occupation, authority and marriage. According to Anderson the migration of Kāi Tahu did not occur as one mass of people moving south, there were waves of migration from the North Island and different sectors of people.

There are a series of events that occured in a relatively short timeframe that explain Kāi Tahu's position at the harbour entrance of the Otago Peninsula. ${ }^{10} \mathrm{I}$ will discuss these events in some detail, illustrating the breadth of history from a pre-European context retained on the Otago Peninsula. Furthermore, in a sparsely populated landmass like the pre-European South Island of New Zealand, there were only a few places that were dense with historical narrative, Otago Peninsula being one. The depth of identity that was previously only shared by the descendants of Ōtākou is now an identity that many locals experience and affiliate with. This illustrates the strength of Māori identity on the Otago Peninsula. The first known arrival of Kāi Tahu to Otago started with the ancestor Waitai who made his way south leaving behind his siblings and relations, who were known as Kăti Kurī. Kāti Kurī today are known as a sub-tribe of Kāi Tahu. Kāti Kurī were resident in the Wellington area and made their way to the South Island. Waitai had vehemently disagreed with one of his relations, Maru, and was incensed that he didn't take revenge when Waitai thought necessary. Waitai made his way south to the fortified village of Pukekura (Taiaroa Heads) where he became resident. He married Te Rakitauneke's sister, a local Kāti Māmoe chief, and an alliance was established. The pair embarked on a number of skirmishes throughout Otago and Waitai moved south and was eventually killed by local Kāti Māmoe. This was a substantial defeat with only four survivors. ${ }^{11}$

Another maneuver that occurred at a similar time involved a well-known figure named Tarewai who was based at Pukekura. While Waitai was gone he had left the $p \bar{a}$ (village) in the hands of his two brothers and their nephew, Tarewai. There was tension between the more recent inhabitants, like Tarewai and others. The Kāti Māmoe had invited Tarewai and some of his colleagues to a place known today as the Pyramids, near Papanui Inlet on the Otago Peninsula, on the premise that they would help them to build a house. After a days work and kai (food) they started to play some wrestling games and Tarewai was taken by surprise as men held him down and started to cut his stomach open with their

\footnotetext{
${ }^{10}$ There are a number of sources that record these events in some detail, including Anderson (1998), Beaton (nd), Karetai (nd), Potiki (2014) and Tau and Anderson (2008).

"Tahu Pōtiki contests Anderson's timeframe of events. He states that Waitai was killed by Rakitaunuku's grandson and that the key events happened within a possible 50 year timespan. The 'Waitai' Anderson talks of would have to be at least 120 years old towards the end of his years, which is simply impossible. There are other Waitai in the whakapapa and they are not discussed here. This information is supported by diaries and family records including considerable information in te reo Māori. Tahu Pōtiki suggests that this timeframe and the whakapapa is misunderstood because the research is from a narrow sector of information. (p.c.2014)
}

\section{Shima: The International Journal of Research into Island Cultures}

Volume 10 Number 12016 


\section{Potiki: Otago Peninsula}

weapons. According to accounts he was a large and strong man and was able to throw off the attackers and make an escape. However he left behind his mere pounamu (greenstone weapon). ${ }^{12}$ He hid at Hereweka where he healed his wounds with the fat of a weka and planned a return to retrieve his weapon. He eventually returned one night to the village of Kāti Māmoe, who were sitting around a fire admiring his mere pounamu. Tarewai pretended to be another villager by feigning their speech pattern and was handed his weapon and took off into the night. Tarewai eventually returned to Pukekura where Kāti Māmoe had established a pā opposite Pukekura named Rakipipikao. Tarewai successfully created a diversion so that he could run along the beach and back into the safety of his $p \bar{a}$. The spot where he leapt to his safety is named Te Rereka o Tarewai. ${ }^{13}$ Tarewai and his uncles then sought revenge on Kāti Māmoe over a period of time pursuing them into Southland. Tarewai met his demise in Fiordland. ${ }^{14}$

The next event started in Kaikoura (towards the northern end of the South Island), the stronghold of Kāti Kurī. Tukiauau and some others left the village in Kaikōura to come south. His departure was possibly connected to Waitai's exit from the area and he was concerned that the Kāti Kurī were in pursuit of him. His relation, Tūwiriroa agreed to provide a safe haven for Tukiauau at his $p \bar{a}$ on the Taieri plains. Tukiauau's son Korokiwhiti fell in love with Tūwiriroa's daughter, Hākitekura. However there was news of an avenging war party and plans were made to escape. It was in haste that Hākitekura lost her life as she leapt from a cliff to the river and fell on to rocks. Tukiauau and his followers fled to Stewart Island and were all killed by Tūwiriroa, who sought revenge for the loss of his daughter. He allowed two to live, the sons on Hākitekura and Korokiwhiti, who were raised by Tüwiriroa in his $p \bar{a}$ on the Taieri Plains. The boys were raised on the stories of revenge relating to the death of their father and in time they took it upon themselves to retaliate. They went north to recruit some fighters, including one named Tüparitaniwha, and planned an attack on Kāti Māmoe in Ōmoua, in Taieri. They discarded their original attack strategy when they realised that Kāi Māmoe were well defended. They then established another p $\bar{a}$ further up the Taieri River and eventually invited the people of Ômoua to a feast in their village, as a ploy to attack them. In the midst of this, a respected Kāi Tahu chief named Tūhōkairangi was killed. This then allowed Kāi Tahu from Kaiapoi and Kaikoura to open a full-scale attack on the people of Taieri in retaliation for the death of Tūhōkairangi. This resulted in a very significant battle named Tarerekiwhenuauta.

In the aftermath of the battle were significant marriages and alliances between the parties that the people of Ōtākou on the Otago Peninsula descend from. These strategic marriages provided the platform for the final set of events ensuring Ōtākou had the mana (prestige) in the wider Dunedin district and further south. Kāti Māmoe had been removed from Papanui and Taieri in the previous battles and there were years of peace. In Karitane, which can be seen on a Peninsula north of Pukekura, Te Wera had built a $p \bar{a}$ named Huriawa. Te Wera was closely connected, as were all in this region, following the complex set of marriages and births. Tensions had grown between the hapu in the two different $p \bar{a}$, Huriawa and Pukekura. Tūkitaharaki, the eldest son of the chief of the village of Pukekura

\footnotetext{
${ }^{12}$ In some whānau accounts the mere was described as a mere paraoa (whale bone mere)

${ }^{13}$ Tarewai's Leap is the translation of this place name. This spot is not visible now due to work completed in the Pilots beach area at Taiaroa Heads that has changed the landscape.

${ }^{14}$ He was killed at Preservation Inlet (p.c., circa 2013).
} 


\section{Potiki: Otago Peninsula}

at this time, fell ill and died. Tūkitaharaki's brother, Kāpō, blamed his cousin, Te Wera for his death, claiming that he had enacted makutu (ie magic) ${ }^{15}$ on him. Kāpō took it upon himself to seek revenge and pursued Te Wera to a house in Pūrākaunui. Te Wera managed to escape while others were killed, and swam back to Huriawa, gathered his people and made their way to the mouth of the Otago Harbour to attack. Te Wera started by beheading two women he came upon on the beach of Te Rauone and sailed past Pukekura with their heads raised. This was Te Wera's attempt to conclude the fighting here having enacted his utu (revenge) for the deaths at Pūrākaunui. Te Wera then attempted to meet with his cousin Taoka whose position between the opposing parties was as an intermediary. However Taoka ignored his request and this angered Te Wera who then went to kill Taoka's son. Te Wera then made an attempt at Pukekura Pā to try and settle the differences but this ended in a full scale battle in which Kāpō was gruesomely killed (as referred to earlier in the article) Te Wera had won this battle and returned to Huriawa Pā. Taoka heard of the bloodshed and attempted to lay siege on Huriawa Pã and Taoka but the strong palisades meant that they couldn't get inside. They surrounded it and waited for six months and eventually Te Wera made an attempt to escape. Taoka went in pursuit of Te Wera, attacking a $p \bar{a}$ they were inhabiting named Māpoutahi and killing all in there. He threw the bodies in to the sea and they were heaped in a pile on the shore like logs, hence the name of the area today, Pūrākaunui ('Bodies heaped up like logs'). Te Wera made his escape to Stewart Island and Taoka reinstated Moki's whānau as the guardians of Pukekura and the land around it. Taoka continued to confront any possible uprisings from the opposition, eventually extinguishing any possibility of attack on the Otago Peninsula and in the wider Otago area.

There were a few further altercations between Kāti Māmoe and Kāi Tahu (but nothing as significant as the previous battles) and there were some marriages and alliances that further cemented peace in the area. It is thought that fortified villages such as Pukekura and Huriawa were abandoned and sub-tribes settled in areas near these $p \bar{a}$ sites. Following the skirmishes at Pukekura and a brief period of asserting dominance, the Ôtākou people enjoyed a relatively settled period with no external threats and formalised peace-making arrangements with sub-tribes to the north. It is most likely by this time Captain Cook had already visited the Fiordland area and the area thrived in the period from the $1820 \mathrm{os}$ on. The food sources were abundant in and around the Otago Peninsula. As Wakefield stated in 1844, "the waters of the harbour teem with fish of the best sorts. The hapuka is taken in great quantities near the shipping town (Port Chalmers); flat fish and oysters in all the bays" (Evison, 1993: 205).

The consolidation of the actual place of Ōtākou on the Otago Peninsula in the place where it stands as a village today is complex. However by the 1860 s the well-known Ōtākou kaik was established and cemented in place. It has been well recorded during early European contact that there were a number of villages before that time in the area known as Ôtākou however the picture of this area is complicated. Settlements were dotted from the mouth of the Otago Harbour to the area now known as Harwood Township. Anderson states that "the settlement pattern in Otago Harbour and nearby had changed considerably between about 1750 and 1850" (1998: 167). Anderson claims that there were five small villages with associated traditional food storehouses (whata) in and about the mouth of the harbour heading towards Harwood Township. Moving towards the mainland from the Headland,

${ }^{15}$ Makutu - a form of magic power that has bad or evil connotations. 


\section{Potiki: Otago Peninsula}

there was a village named Takiharuru near the beach on the headland, another settlement south of this called Rakipipikao and the next large settlement was Ruatitiko. Following Ruatitiko ${ }^{16}$ was Tahakopa. Along past Wellers Rock was Ōmate and another further south named Ōhinetū. These were the primary post contact villages on the eastern Otago Peninsula. John Boultbee recorded in 1828 that "Kaika Otargo", as he wrote it, was the largest and oldest of the southern settlements (Begg and Begg, 1979: 271).

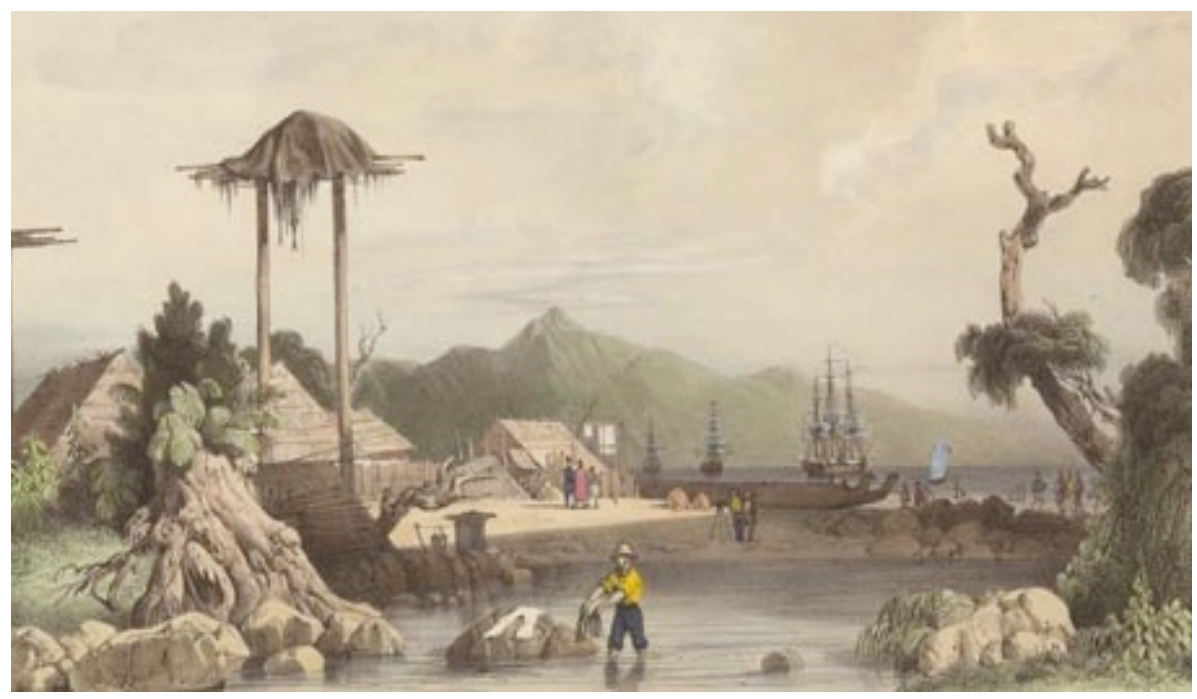

Figure 3 - The village of Ruatitiko on the Otago Peninisula painted by Le Breton in 1840 Source: http://www.teara.govt.nz/en/artwork/22607/ships-in-otago-harbour-1840

\section{Cultural Encounters}

The first European encounter with the Peninsula occurred as Captain Cook sailed past the entrance of the Otago Harbour in February 1770 as a wind pushed the Endeavour further out to sea. He named a point on the Peninsula Cape Saunders as he sailed passed (Church, 2008: 8). Papanui Inlet is separated from Hoopers Inlet by a strip of land that is an isthmus connecting to a hilly peninsula containing Cape Saunders and the peninsula's highest point, the 408-metre Mount Charles. This area was occupied by Māori at different periods. Skinner (1960) claims that archaeological excavations at Little Papanui in the years 19201940 yielded far more archaeological material than any other site in Otago. Eventually, Cape Saunders was turned into farmland by the earliest European settlers to the Otago Peninsula. Following this encounter, sealers, who were working mainly in the Fiordland area, made their way into the Otago Peninsula harbour in the early 1800 . ${ }^{17}$ Ôtākou

\footnotetext{
${ }^{16}$ The village of Ruatitiko eventually succumbed to a sandy grave with the deforestation of the area. According to our people this village had a church built from punga and raupō and the houses were a combination of European and Māori style.

${ }_{17}$ "Sealing commenced in New Zealand in the late 18th century and continued until about 1820, when the seal populations were depleted to the extent tha the industry was no longer economically viable" (Coutts, 1985: 31).
}

\section{Shima: The International Journal of Research into Island Cultures Volume 10 Number 12016




\section{Potiki: Otago Peninsula}

harbour had rapidly become a commercial anchorage where Europeans could purchase pigs, flax, potatoes and fresh water and quality timber for boat repairs. Māori were eager to be a part of the trade and saleable operations from the outset. Anderson remarks that "Māori potato cultivation was extensive by the mid-183os" and shipments of tons of potatoes were being sent to Sydney and that "[p]ork, muttonbirds and dried and salted fish were also sent from Ōtākou" (1998: 173) The focus of commercial activity was at the mouth of the Otago Peninsula, whereas the mainland was thick with forest, and pigs were eventually let to run there. However, there was no record of occupation on the mainland. In 1844 Monro made the following observations about the mouth of the harbour of the Peninsula:

The sky, a great part of the time, was without a cloud, and not a breeze ruffled the surface of the water, which reflected the surrounding wooded slopes, and every sea-bird that floated upon it, with mirror-like accuracy. For some hours after sunrise, the woods resounded with the rich and infinitely varied notes of thousands of tuis and other songsters. I never heard anything like it before in any part of New Zealand. (Monro, 1844)

He goes on to state that there is 'absence of a good site for a town". He also mentions how inhospitable the bushland is on the mainland and that whalers have mentioned how they never venture in. The Peninsula was abundant with resources and water and this was naturally what drew the first Europeans to the area.

One well-known character who was one of the first European residents in the area was William Tucker. He took advantage of Māori technology, trading their greenstone necklaces (heitiki) and was said to have been the first man to trade a preserved Māori head in Sydney in 1811 (Church, 2008: 55). He also took a Māori wife in his time in the area and was involved in skirmishes with Māori and met his demise as a result. He was killed by a Māori from the area named Te Matehaere in an incident concerning trade involving Captain James Kelly and the Sophia in 1817 (Church, 2008: 80-82). European vessels did not enter the harbour for up to six years following this incident. Whalers also rolled up on the shores of the Otago Peninsula bringing entrepreneurial acumen with them. The combination of the whaling station and the general influx of Europeans to the area drew people to the area known as Ōtakou today. The Weller brothers (Edward and Joseph) set up a very successful whaling station at Te Umukurī (Wellers Rock) on the Peninsula in 1831. They took Māori wives from Ōtākou and their descendants are a part of the contemporary social fabric of Otago Peninsula. ${ }^{18}$ The Weller brothers traded many commodities including whale oil, flax, fish, spars and seal-skins. While they established other whaling stations in the wider Otago area, the commercial business was run between Ōtākou and Sydney and New South Wales. Although they faced hostility from some local Mãori people, Māori were also heavily involved in the whaling stations and it is questionable how successful the Weller operations would have been without the input of Māori labor, land and good relationships. Furthermore, reports alluded to the high moral standards and astute behavior of Māori in this period. In 1836 Haberfield commented that:

those engaged at Weller's were entitled, as well as whites, to a gill of rum every morning before going out; and d'ye know what the Maori did? They

\footnotetext{
${ }^{18}$ The author is a descendant of Edward Weller and Nikuru Taiaroa.
} 


\title{
Potiki: Otago Peninsula
}

carefully bottled it off as they got it, and afterwards sold it to the white people at a little less than the price at the store. (Church, 2008: 262)

Eventually, well-known Māori figureheads from Ōtākou, such as Karetai and Taiaroa, began travelling to places as far afield as Sydney for trade. They owned their boats and hired Europeans to work for them. The children of these men were to be faced with the swiftest of change and the most challenging of losses. The interface of Māori and European on the Otago Peninsula in this short period opened the floodgates and the tide of modernity was unstoppable. Hayward discusses the vulnerability of islands and the indigenous people of the Otago Peninsula were no exception:

\begin{abstract}
Islands' locations - and particularly their relation to sea routes - can imbue them with significance as pivotal and/or connecting points within histories of 'discovery', exploration, population movement and/or trade. Some islands are thereby vulnerable to appropriation and elevation within external heritage agendas. I characterize this as a 'vulnerability' (rather than an opportunity or advantage) since it is the global discourses and significance that attract 'heritagization' in these formations rather the specificities of islands' internal places and indigenous histories. (2008: 170)
\end{abstract}

\section{Change on the Otago Peninsula}

At a point in time Māori on the Peninsula were in charge of their own destiny. They were working with Europeans with the ability to create wealth from their own commodities and maintain their traditional lifestyle. However this freedom was swiftly constrained with the needs and expectations of a growing colonial population. I will discuss some key events that lead to the change and gave rise to a unique Peninsula landscape.

In 1836, the ship, The Sydney Packet arrived at Ōtākou with a few influenza cases on board. "Immediately the disease attacked the Mãori and the people died in hundreds reducing the population to an alarming degree" (Pybus, 1954a: 56). Following the decimation of the Ōtākou Mãori population came the loss of land. This began with the Treaty of Waitangi, which was led by Major Bunbury in the Kāi Tahu tribal region in order to obtain the signatures of the Southern Mãori. The Treaty had been signed by many iwi (tribes) in the North Island and on the 13th June 1840 Korako and Karetai signed the Treaty at Taiaroa Heads. They were amongst seven of the signatories for Southern Mãori. The premise in their hearts and minds was that they accepted that under the Treaty they would retain their lands and have equal protection and rights as British citizens. The ongoing political struggle over the total disregard to the promises agreed to in the Treaty of Waitangi would continue for one hundred and fifty years. After the signing of the Treaty came the most significant contractual breech for Mãori on the Otago Peninsula.

The British Crown eventually came under pressure from the New Zealand Company ${ }^{19}$ and waived its right of pre-emption, as stated in the Treaty of Waitangi, allowing the New

\footnotetext{
19 "In 1840 the first immigrants assisted by the New Zealand Company arrived in New Zealand. The company introduced long-term settlers directly from Britain, "as opposed to those who travelled across the Tasman simply to harvest resources or souls" (Phillips, 2013: online).
}

\author{
Shima: The International Journal of Research into Island Cultures \\ Volume 10 Number 12016 \\ $-80-$
}




\title{
Potiki: Otago Peninsula
}

Zealand Company to negotiate with the local chiefs for the purchase of land in the south. The New Zealand Company and the Free Church of Scotland selected the area at the head of the harbour, on the mainland for a permanent site to be called New Edinburgh. Frederick Tuckett, a surveyor for the New Zealand Company, was assigned to oversee the purchase of the site. George Clarke wrote an account of the proceedings in Otago that included Tuckett, surveyors and local Māori in 1844. They had come to survey the land for a "New Edinborough, the Dunedin of the future" (Pybus, 1954b: 108).

The Maoris knew too much about the Company's purchases in the North and did not believe in making over the whole block and then leaving it to us to say what proportion should be assigned to them, nor would they hear of parting with their village cultivations and burial grounds. I had a hard fight with Tuckett and Wakefield to make the reserves and put them into the deed. These proposed reserves lay almost wholly in the Peninsula on the eastern side of the Bay, while, naturally enough, Col. Wakefield was as anxious to buy the Peninsula as the Maoris were to retain it. (Pybus, 1954b: 109)

Kāi Tahu wanted to keep 21,250 acres of Otago Peninsula with ancestral sites for themselves. However, the Europeans did not agree and would not proceed with the sale unless the Peninsula was included (Evison, 1993: 205). The Māori conceded to accept only the land at the northern end of the Peninsula, and a few other areas outside of that including, 9,612 acres total. On July 31st, 1844 at Koputai (opposite the Peninsula - Port Chalmers today) twenty five chiefs signed the Otago deed (around 400,000 acres) for $£ 2,400$. Of the 400,000 acres, 150,000 acres would be chosen for the New Edinburgh site. In addition to this land, verbal agreements were made to reserve $10 \%$ of all land sold, known as 'the tenths', in trust for the benefit of Kāi Tahu. The agreement was not honoured and the work on New Edinburgh on the mainland began in 1846. The organised settlement of the suburban and rural areas of the Peninsula began in 1848 and focused on Anderson's Bay and Portobello. The Peninsula was divided into farms of about 50 acres that were gradually occupied and supplied a growing Dunedin with food. West states that:

\begin{abstract}
the sale of Otago Block to the New Zealand Company in 1844 was by far the most significant event that shifted control over the Peninsula, the Ōtäkou mäori were stranded on the northern tip of the Otago Peninsula, confined to meager portions of their once vast property. The way was thereby opened to the European settlement, and the making of a new environment on the Otago Peninsula. (2009, 265)
\end{abstract}

The Emergence of a unique Peninsula

The Peninsula communities remained relatively isolated through to the mid zoth Century. A high road on the backbone of the Peninsula was the first to be built and from the 1860 s on Scottish farmers settled here. They burnt off the bush and sectioned off paddocks with rock walls. Dairy farming took a hold and fed into the communities on the Peninsula. These long-standing farming families are now a part of the fabric of the Peninsula. The coast road from the mainland to the Peninsula was difficult to traverse and was not tarsealed until the 1950s. In 1897 a petition was taken round to improve the road, "and was signed by nearly everyone in the district, asking the Government to complete the road through to Portobello. If this is done it will greatly improve the means of communication

\author{
Shima: The International Journal of Research into Island Cultures \\ Volume 10 Number 12016 \\ $-81^{-}$
}




\section{Potiki: Otago Peninsula}

between Dunedin and the Kaik" (Otago Witness, 1897: 30). My grandfather, George Ellison, was born in 1907 on a farm at Ōtakou. His parents sent him to secondary school on the mainland. In 1989 he told me that he would wake early to milk cows, travel by horse to Portobello, cross by boat to Port Chalmers and train to Otago Boys High School in Dunedin.

Mainlanders visited various parts of the Otago Peninsula in the late 18oos, including Ōtākou, the local maraeand the church and would often cross from Port Chalmers by boat and moor off the Peninsula. In 1897 The Otago Witness wrote of visitors to the Peninsula: "It is hoped our town visitors enjoyed the combination of fresh sea breeze and country air, freely mixed with the scent of decaying whale feed, with which the beach at the Kaik is covered at the present time" (1897: 25). Eventually some mainlanders built cribs (holiday homes) on the Peninsula to use in the summer. At Ôtākou these cribs are built on Māori land that is leased. Although only 25 kilometres from the mainland, the view of the Otago Peninsula as a holiday destination continues to create a sense of isolation and distance. Despite the short distance from the mainland and the city of Dunedin, the Peninsula peoples have developed their own identity, which is rooted in this deeper association with the land. The broader identity of Otago has now been heavily influenced by wildlife on the Peninsula that has been extensively restored. Albatrosses, seals, penguins, whales and so forth are treasured by the Peninsula communities. Ironically what originally brought Europeans to the shores of the Peninsula to exploit now brings visitors to view and enjoy. The distinctive vibe and culture of the Otago Peninsula derives from the blend of Mãori and European people who have occupied the Peninsula with a fierce connection to and pride for their place. History, whakapapa and the modern communities that were born out of this, will ensure the Otago Peninsula remains a distinct community from the mainland. However the wave of outsiders to the Peninsula has indeed challenged our cultural landscape. The connection to the city and its culture is stronger than that to the Peninsula and its culture. The increased mobility and access based on roads, and communication brings ideas from the outside that challenge a pristine Peninsula culture. Indigenous identity on the Peninsula is relegated to a particular location and confused with guardianship of the environment ('Mother Earth') and some sort of spiritual connection that is barely understood. Māori on our Peninsula need to be vigilant in their transmission of knowledge to the following generations lest we become invisible, absorbed into the conglomerate of a new and emerging Peninsula community.

\section{Bibliography}

Anderson, A (1983) When all the moa-ovens grew cold: Nine centuries of changing fortune for the Southern Maori, Dunedin: Otago Heritage Books

----- (1998) The welcome of strangers: an ethnohistory of southern Maori A.D. 1650-1850, Dunedin: Otago University Press in association with Dunedin City Council

Ballara, A (1998) IWI, The dynamics of Māori tribal organisation from c. 1769 to c. 1945, Wellington: Victoria University Press

Baldacchino, G (2008) 'Studying Islands: On Whose Terms? Some Epistemologial and Methodological Challenges to the Pursuit of Island Studies' in Island Studies Journal v3 n1: 37-56

Beaton, H (nd) Personal Diary, held at the Ngāi Tahu Archives in Christchurch

\section{Shima: The International Journal of Research into Island Cultures}

Volume 10 Number 12016 


\title{
Potiki: Otago Peninsula
}

----- (1915) Personal Notebook, held at Hocken Library, Dunedin

Beattie, H (1920) 'Traditions and Legends Collected from the natives of Murihiku (Southern New Zealand)' part XIII, Journal of The Polynesian Society v29 n116: 128-138, 189-198

----- (1944) Maori Place names of Otago, Dunedin: Otago Daily Times and Witness Newspapers Ltd.

----- (1949) The Maoris and Fiordland, Dunedin: Otago Daily Times

Begg, A.C and Begg, N.C (1979) The World of John Boultbee, Christchurch: Whitcoulls

Church, I (ed) (2008) Gaining a Foothold, Historical Records of Otago's Eastern Coast 1770 - 1839, Dunedin: Friends of the Hocken Collections

Cowan, J (1987) Legends of the Maori (Volume 1) City: Southern Reprints

Coutts, P.J.F (1985) 'Towards the Development of Colonial Archeaology in New Zealand: Part 2: Early Settlement Patterns in Southern New Zealand', Australian Journal of Historical Archaeology v3: 31-42

Durie, E (1996) 'Will the Settlers Settle?' Otago Law Review v8 n4: 449-465

Ellison, E (2011) 'Application for resource consents for Project Next Generation by Port Otago Limited', Te Runanga o Otakou 2

Entwisle, P (1998) Behold the Moon The European Occupation of the Dunedin District 1770-1848, Dunedin: Port Daniel Press

Evison, H C. (1993) Te Wai Pounamu The Greenstone Island, Christchurch: Aoraki Press

----- (2006) The Ngāi Tahu Deeds, A window on New Zealand History, Christchurch: Canterbury University Press

GNS Science (2015) 'Dunedin Volcano': http://www.gns.cri.nz - accessed January 3oth 2016

Hau'ofa, E(1998) 'The Ocean in Us', The Contemporary Pacific v1o n2: 391-410

Hayward, P (2008) 'Les Meduses dans la Maree de L'Histoire: L'Anse Meadows, Nan Sdins and Cultural Heritiage Agendas', Island Studies Journal v3 n2: 163-174

Karetai, E (nd) Personal Diary, Author's private collection

Kelly, J (1999) 'Māori Maps' , Cartographica: The International Journal for Geographic Information and Geovisualization v36 n2: 1-30

Monro, D (1844) 'Notes of a Journey through a part of the Middle Island of New Zealand', The Nelson Chronicle v3 n128: 96

Morris, R \& Forsyth, J (1986) Almost an Island - Guide to Otago Peninsula, Dunedin, John McIndoe

New Zealand Geographical Board (1990) He Kōrero pūrākau mo ngā taunahatanga a ngā tūpuna, Place names of the Ancestors, A Mãori oral History Atlas, Wellington: Government printing office

Nash, J (2012) 'An Insular Toponymy: Place naming on Dudley Peninsula, Kangaroo Island' Transaction of the Royal Society of South Australia v136 n2: 67-96

---- (2014) 'Norfolk Pitcairn Bounty: Myth Narrative Place', Te Reo n56/57: 177-19o

\author{
Shima: The International Journal of Research into Island Cultures \\ Volume 10 Number 12016 \\ $-83^{-}$
}




\section{Potiki: Otago Peninsula}

Nash, J and Low, M (2015) 'Language and Place Knowledge on Norfolk', Ethnos v8o n3: 385-408

O'Regan, T (2003) 'Old Myths and New Politics: Some Contemporary Uses of Traditional History', Journal of New Zealand History v26 n1: 5-27

Otago Witness Newspaper (1897) lineage item, n2261, July 1st: 30

Phillips, J (2013) 'History of immigration - British immigration and the New Zealand Company', Te Ara

- the Encyclopedia of New Zealand: http://www.TeAra.govt.nz/en/history-of-immigration/page-3

Pōtiki, M (2015) 'Me tā tāua mokopuna, The te reo māori writings of HK. Taiaroa and Tame Parata', New Zealand Journal of History v49 n1: 31-53

Pōtiki, T (2014) Thematic Report for Kāi Tahu ki Otago, unpublished report

Prendergast-Tarena, E.R (2008) 'He Atua, He Tipua, He Takata ranei. The Dynamics of change in South Island Maori oral traditions', (unpublished) Masters thesis, University of Canterbury, Christchurch.

Pybus, T.A (1954a) The Maoris of the South Island, Wellington: A.H \& A.W Reed

Pybus, T.A (1954b) Māori and Missionary, Early Christian missions in the South Island of New Zealand, Wellington: A.H and A.W Reed

Reed, A.H and A.W (ed) (1951) Captain Cook in New Zealand - Extracts from the Journals of Captain James Cook, Wellington: A.H and A.W Reed

Taiaroa, H.K. (1865) Patu Taipō, Diary of H.K. Taiaroa, Private Collection, Ōtākou

Tau, T (2001) 'The Death of Knowledge, Ghosts on the plains', The New Zealand Journal of History v35 n2: 131-152

Tau, T. and Anderson, A (2008) Käi Tahu: A Migration History: The Carrington Text, Christchurch: Bridget Williams Books in association with Te Rūnanga o Ngāi Tahu

Taylor, W.A (1950) Lore and History of the South Island Maori: Bascands Limited

Skinner, H.D (1960) 'Excavations at Little Papanui, Otago Peninsula', The Journal of the Polynesian Society v69 n3: $187-198$

Sorrell, P and Warman, G (2013) Peninsula, Exploring the Otago Peninsula, Auckland: Penguin Books

Stevens, M.J (2011) “Whats in a name?": Murihiku, Colonial knowledge-making, and "thin culture"', The Journal of the Polynesian Society v120 n4:333-347

Stratford, E, Baldacchino, G, McMahon, E, Farbotko, C and Harwood, A (2011) Envisioning and Archipelago, Island Studies Journal v6 n2: 113-130

West, J (2009) 'An Environmental History of the Otago Peninsula' (unpublished) PhD thesis, Otago University, Dunedin

\section{Shima: The International Journal of Research into Island Cultures Volume 10 Number 12016

